\title{
Subsidiary strategy of emerging market multinationals: a home country institutional perspective
}

Article

Accepted Version

Creative Commons: Attribution-Noncommercial-No Derivative Works 4.0

Wei, Z. and Nguyen, Q. T. K. (2017) Subsidiary strategy of emerging market multinationals: a home country institutional perspective. International Business Review, 26 (5). pp. 10091021. ISSN 0969-5931 doi:

https://doi.org/10.1016/j.ibusrev.2017.03.007 Available at https://centaur.reading.ac.uk/69854/

It is advisable to refer to the publisher's version if you intend to cite from the work. See Guidance on citing.

To link to this article DOI: http://dx.doi.org/10.1016/j.ibusrev.2017.03.007

Publisher: Elsevier

All outputs in CentAUR are protected by Intellectual Property Rights law, including copyright law. Copyright and IPR is retained by the creators or other copyright holders. Terms and conditions for use of this material are defined in the End User Agreement.

www.reading.ac.uk/centaur

\section{CentAUR}


Central Archive at the University of Reading

Reading's research outputs online 
SUBSIDIARY STRATEGY OF EMERGING MARKET MULTINATIONALS:

A HOME COUNTRY INSTITUTIONAL PERSPECTIVE

\author{
Ziyi Wei (Ph.D.) (Corresponding Author) \\ School of East Asia Studies \\ University of Sheffield \\ 6-8 Shearwood Road, Sheffield S10 2TD, the United Kingdom \\ E-mail: z.wei@sheffield.ac.uk \\ Quyen T.K. Nguyen (Ph.D.) \\ Henley Business School, International Business and Strategy \\ University of Reading \\ Whiteknights Campus, Reading RG6 6AH, the United Kingdom \\ E-mail: t.k.q.nguyen@henley.ac.uk
}




\title{
SUBSIDIARY STRATEGY OF EMERGING MARKET MULTINATIONALS: A HOME COUNTRY INSTITUTIONAL PERSPECTIVE
}

\begin{abstract}
We examine the effects of home country institutional factors, namely, home country government support, domestic institutional weaknesses, and state ownership on the subsidiary-level strategy of global integration (I) and local responsiveness (R) of emerging market multinational enterprises (EMNEs). We draw upon the home country institution-based view and the I/R framework to develop our theoretical model. We empirically test our hypotheses using an original new survey data collected from Chinese multinational subsidiary managers supplemented with parent-level and country-level data. We find that home country government support and domestic institutional weaknesses have significant and negative effects on global integration strategy of Chinese multinational subsidiaries. On the other hand, domestic institutional weaknesses push foreign subsidiaries to pursue local responsiveness strategy. Nevertheless, those with greater degree of state ownership in their parent firms are neither willing to disintegrate from their parent firms nor motivated to pursue local responsiveness strategy in order to deal with home country institutional deficiencies and develop new sources of competitiveness in foreign markets. Our findings have advanced the literature on subsidiary strategy in the context of EMNEs, and provide important implications for subsidiary managers and policy makers.
\end{abstract}

Key words: subsidiary strategy; global integration; local responsiveness; Chinese multinational subsidiaries. 


\section{SUBSIDIARY STRATEGY OF EMERGING MARKET MULTINATIONALS: A HOME COUNTRY INSTITUTIONAL PERSPECTIVE}

\section{Introduction}

The majority of previous studies on emerging market multinational enterprises (EMNEs) focus on parent-centric decisions in outward foreign direct investment (OFDI), such as choices of establishment modes, ownership structure, and host country locations (e.g., Cui \& Jiang, 2012; Hong, Wang, \& Kafouros, 2015; Lu, Liu, Wright, \& Filatotchev, 2014; Meyer, Ding, Li, \& Zhang, 2014). Yet, little is known about EMNEs' subsidiary strategies, which reflect a notable research gap. We aim to address this limitation in our study.

Subsidiary strategy suggests some level of choice or self-determination on the part of the subsidiary (Birkinshaw \& Hood, 1998; Birkinshaw \& Pedersen, 2009). The underlying premise of subsidiary strategy is that decisions are made by subsidiary managers in their marketplace, not by headquarters (HQs) managers (Garcia-Pont, Canales, \& Noboa, 2009; Rugman \& Verbeke, 2001; Rugman, Verbeke, \& Nguyen, 2011).

Birkinshaw \& Pedersen (2009) argue that a distinction needs to be made between the concepts of subsidiary role and subsidiary strategy. A subsidiary role is assigned to it by the parent firm, and the subsidiary is simply to follow orders. Subsidiary strategy involves the decision-making power and entrepreneurship of the subsidiary in its value-adding activities independently from the parent firm and other subsidiaries (Garcia-Pont et al., 2009; Nguyen \& Rugman, 2015a, 2015b).

Much of our knowledge on subsidiary strategy comes from research in the context of advanced economy MNEs (Birkinshaw, 1995, 1996; Birkinshaw \& 
Morrison, 1995; Mauri \& Phatak, 2001; Nguyen \& Rugman, 2015a, 2015b). The literature documents the diversity of subsidiaries driven by their specific strategic roles, the importance of external embeddedness in host country environments, and internal embeddedness within MNEs (Andersson, Forsgren, \& Holm, 2002; Hoenen \& Kostova, 2014; Meyer, Mudambi, \& Narula, 2011). Furthermore, highly-developed institutions allow MNEs from advanced economies to build and accumulate firmspecific advantages (FSAs), especially managerial skills, integration systems of organizing, and coordinating and orchestrating activities of a spatially dispersed network of foreign subsidiaries (Kostova \& Roth 2002; Wang, Luo, Lu, Sun, \& Maksimov, 2014).

In contrast, EMNEs are latecomers in the world stage, originating from complex and weak domestic institutional environments (Luo \& Tung, 2007; Luo, Xue, \& Han, 2010; Pan, Teng, Supapol, Lu, Huang, \& Wang, 2014). Home country institutions are a source of advantages and disadvantages for EMNEs (Rugman, Nguyen, \& Wei, 2014). On the one hand, home country government support and state ownership provide EMNEs necessary resources to embark on internationalization (Lu et al., 2014; Wang, Hong, \& Kafouros, \& Wright, 2012). On the other hand, domestic institutional weaknesses create disadvantages for EMNEs' foreign subsidiaries due to the liabilities of origin, which emerge as a direct consequence of the national origins of EMNEs (Bartlett \& Ghoshal, 2000; Ramachandra \& Pant, 2010).

The liabilities of origin can affect EMNEs and their foreign subsidiaries through a variety of processes, such as organizational imprinting and identity, image, capability development and resource scarcity (Ramachandra \& Pant, 2010). Because EMNEs' foreign subsidiaries are associated with the weak institutional heritage in home countries, their corporate images and legitimacy in host countries are unfavorable (Luo 
\& Tung, 2007; Madhok \& Keyhani, 2012; Wang et al., 2014). Furthermore, weak domestic institutions have impeded EMNEs to develop traditional Western-type FSAs in technology, global brands, and managerial expertise (Hennart, 2012; Rugman, 2010; Wei, 2010). These create additional costs and challenges of doing business abroad for EMENs' foreign subsidiaries.

In this study, we argue that subsidiary strategies play an important role for EMNEs, in which home country institutions are critical factors influencing the strategic behaviors of EMNEs' foreign subsidiaries. We elaborate on the home country institution-based view and the global integration and local responsiveness (I/R) framework in developing our conceptual model and hypotheses. The central idea of the $\mathrm{I} / \mathrm{R}$ framework is that on the one hand, the MNE exploits the benefits of economies of scale and scope across national borders and must balance the need to be responsive to preferences and tastes of local consumers and governments' regulations on the other hand (Bartlett \& Ghosbal, 1989; Prahalad \& Doz, 1987). This strategy is called “transnational solution” by Bartlett \& Ghoshal (1989).

Our study addresses a key research question "to what extent do home country institutions (i.e. home country government support, domestic institutional weaknesses, and state ownership) affect the IR strategies of EMNEs' subsidiaries after they enter foreign markets?" We deem that the foreign subsidiaries of Chinese MNEs are a particularly interesting research context. The surge of Chinese OFDI has been largely attributed to China's "go global" policy and home country government's direct involvement in the allocation of firms' resources, which in turn affect their internationalization behavior (Buckley, Clegg, Cross, Liu, Voss, \& Zheng, 2007; Luo et al., 2010; Wang et al., 2012).

Furthermore, institutional variations in China affect subsidiary strategies of 
Chinese MNEs through various mechanisms. These include the characteristics of parent firms, such as the degree of state ownership, and government affiliation and political connections (Cui \& Jiang, 2012; Duanmu, 2014; Liang, Ren, \& Sun, 2015; Pan et al., 2014; Wang et al., 2012); regional locations in China (Hong et al., 2015); the nature of FDI projects, such as the level of compliance with government FDI policies (Lu et al., 2014; Hong et al., 2015), and the home-host political relations (Chen \& Young, 2010; Duanmu, 2014).

We make three new contributions to the literature. First, we advance the extant literature on EMNEs with a specific focus on EMNEs' subsidiary strategies. We obtain subsidiary managers' insights through a survey with Chinese multinational subsidiaries for our empirical tests. We also supplement our primary survey data with secondary data from multiple sources, including parent-level data from company annual reports, and country-level data from public sources. Thus, our theoretical and empirical approach differs from Wang et al., (2014) which examines parent-centric decisionmakings and autonomy delegation to foreign subsidiaries as an enabling mechanism for EMNEs; however, they use data from a survey with HQs executives of Chinese parent firms.

Second, our work advances the literature of subsidiary strategies because many of the previous studies only focus on how multinational subsidiaries adapt to host country institutional environments (Kostova \& Roth 2002; Luo, 2001, 2003). Given that EMNEs originate from unique and complex institutional environments, we explicitly delineate their foreign subsidiaries' strategies as responses to home country government support, domestic institutional weaknesses, and state ownership. Furthermore, our analysis on the influence of state ownership on subsidiary strategies is a new and interesting contribution, because this phenomenon has been largely 
neglected in the existing literature. Our study provides insights into the role of state ownership in enforcing EMNEs' competitiveness or aggravating their disadvantages in international markets.

Third, we extend the I/R framework by analyzing it in the context of EMNEs' subsidiaries. While the $\mathrm{I} / \mathrm{R}$ framework emphasizes the dual achievement of global integration and local adaptation for advanced economy MNEs, it might be challenging for EMNEs due to their lack of managerial skills in coordinating and managing a geographically dispersed network of foreign subsidiaries (Fan, Nyland, \& Zhu, 2008; Morck, Yeung, \& Zhao, 2008; Rugman \& Li, 2007). Our study is among the first few attempts which investigate how EMNEs' subsidiaries balance integration and responsiveness as responses to domestic institutional advantages and disadvantages. Accordingly, we broaden the theoretical knowledge of the I/R framework by examining its implications on EMNEs.

\section{Theoretical background}

\subsection{Subsidiary strategy of global integration and local responsiveness}

Global integration is driven by economies of scale and scope, cost reduction, and resource intensity, in which MNEs standardize their production and distribution of homogenous products and services on a worldwide basis. In contrast, local responsiveness is the ability of MNEs to understand local market variations in consumer tastes, and demands in segmented markets, and to respond to different national standards and regulations imposed by autonomous governments and agencies (Bartlett \& Ghosbal, 1989; Prahalad \& Doz, 1987).

On the one hand, subsidiaries pursue global integration strategy by relying on parent-firm FSAs developed in home countries, which are internationally transferred at 
low cost and without substantial adaptation in host countries (Rugman \& Verbeke, 1992, 2001; Rugman, 2002; Rugman \& Verbeke, 2008). Global integration is consistent with the view that parent firms' FSAs are critical resources in overcoming the liabilities of foreignness, i.e. additional costs and risks of doing business abroad (Rugman, 2002; Rugman \& Verbeke, 2008).

On the other hand, subsidiary strategy literature emphasizes that FSAs can be developed by both parent firms and by foreign subsidiaries (Nguyen \& Rugman, 2015a, 2015b; Rugman \& Verbeke, 2001; Rugman et al., 2011). Subsidiary initiatives defined as discrete and proactive undertaking of the subsidiary advances are new ways for the MNE to use or expand its resources (Birkinshaw, 1996, 1997; Birkinshaw \& Hood, 1998). Foreign subsidiaries access complementary resources in host countries and create new knowledge, and develop new learning and innovative capabilities, which enable them to reap the benefits of local responsiveness as their local embeddedness increases (Cantwell \& Mudambi, 2005; Nguyen \& Rugman, 2015a, 2015b).

It will be interesting to examine this phenomenon in the context of EMNEs because they lack the traditional knowledge-based FSAs which can be exploited abroad (Peng, 2012; Ramamurti, 2009, 2012; Wang et al., 2014). In other words, compared with MNEs from advanced economies, subsidiaries of EMNEs rely less on their parent firms' FSAs. Therefore, foreign subsidiaries play critically important roles in generating new strategic assets, in establishing local legitimacy and reputation, and in catching up with global competitors.

\subsection{Home country institutions and subsidiary strategy}

Home country institutions create advantages and disadvantages for EMNEs and their foreign subsidiaries. First, resources and capabilities of EMNEs are based on home 
country-specific advantages (CSAs) (Buckley et al., 2007; Rugman \& Nguyen, 2014; Rugman et al., 2014; Rugman, Nguyen \& Wei, 2016). Home country government support (a type of home CSAs) enables EMNEs to embark on internationalization and influences their strategic decisions (Duanmu, 2014; Hong et al., 2015; Wang et al., 2012). On the one hand, government support and assistance may alleviate EMNEs' competitive disadvantages by providing favorable policies, investment information, and low-cost capital (Lu, Liu, \& Wang, 2011; Luo et al., 2010). On the other hand, such institutional incentives toward OFDI may affect EMNE subsidiary managers' perceptions toward resource availability and their capabilities to take risks in foreign markets (Lu et al., 2014; Pan et al., 2014).

Second, EMNEs' foreign subsidiaries suffer from the liabilities of origin as a direct consequence of weak domestic institutions (Madhok \& Keyhani, 2012; Wang et al., 2014). Institutional constraints in emerging economies include both institutional voids (i.e. an absence of intermediaries and regulatory systems which facilitate a wellfunctioning market, such as a lack of effective intellectual property rights protection, poor law enforcement, and underdeveloped factor markets) (Boisot \& Meyer, 2008; Khanna \& Palepu, 2010) and political hazards (i.e. corruption, moral degradation, ambiguous laws, government intervention, and informal competition) (Ramachandran \& Pant, 2010; Witt \& Lewin, 2007).

The liabilities of origin of EMNEs' foreign subsidiaries in host countries refer to the negative institutional heritage associated with poor corporate governance, negative credibility, a lack of accountability and transparency of EMNEs perceived by different stakeholders (Luo \& Tung, 2007; Wang et al., 2014). The liabilities of origin are different from the liabilities of foreignness, which refers to geographical, psychological, and cultural distance between home and host countries (Madhok \& 
Keyhani, 2012).

Firms may overcome the liabilities of foreignness through global integration strategy, in which their subsidiaries rely on parent firms' FSAs in order to compete with local competitors and other global giants in foreign markets (Rugman \& Verbeke, 1992, 2001). Such a strategy best explains market-seeking OFDI in which foreign subsidiaries focus on exploiting parent firm's existing FSA bundles to achieve economies of scale and scope (Ramamurti, 2012). In contrast, firms need to pursue a local responsiveness strategy in order to overcome the liabilities of origin, which are originated from weak domestic institutions which impede firm resource development at parent-level. Foreign subsidiaries develop and/or acquire new FSAs by accessing host CSAs, which may explain strategic asset-seeking OFDI. It is important for EMNEs' foreign subsidiaries to disassociate from their parent firms and to take initiatives in building local legitimacy in host economies (Kostova \& Zaheer, 1999; Wang et al., 2014; Xu \& Shenkar, 2002). EMNEs' foreign investments driven by strategic asset-seeking have been widely recognized in the current literature. EMNEs use their subsidiaries as a "springboard" to develop linkage, leverage, and learning (LLL) of new capabilities in host countries, and to acquire strategic resources, especially through cross-border mergers and acquisitions (M\&As) (Cui \& Jiang, 2012; Luo \& Tung, 2007; Ramamurti, 2012). Overall, the strategies of EMNEs' foreign subsidiaries in response to home country institutions reflect the complex parent-subsidiary relationships.

\section{Hypotheses development}

3.1. Home country government support and the global integration and local responsiveness strategy of the subsidiary 
One important precondition for global integration strategy is that an MNE needs to possess FSAs which can be exploited by their subsidiaries in foreign markets (Rugman, 2002; Rugman \& Verbeke, 2003). However, EMNEs are different from Western MNEs because they derive their competitiveness from home CSAs rather than FSAs (Buckley, Clegg, Cross, \& Voss, 2010; Deng, 2009; Rugman \& Li, 2007; Rugman et al., 2016). Home country government support (a type of home CSAs) includes direct assistance in the form of preferential credit, low-interest bank loans and subsidies, host country information, guidance on direction of OFDI, administrative assistance, and post-investment supervision (Luo et al., 2010; Morck et al., 2008).

First, home country government support downplays the role and importance of existing FSAs as stimulus for MNEs to engage in OFDI. It is one particularly important instrument for EMNEs in their internationalization through establishing foreign subsidiaries (Hong et al., 2015; Nayyar, 2008; Wang et al., 2012). While EMNEs lack knowledge-based FSAs, home country government support reduces foreign subsidiaries' reliance on parent-firm FSAs in offsetting costs associated with the liabilities of foreignness and in competing with local firms (Buckley et al., 2010; Luo \& Tung, 2007; Peng, 2012).

Second, with the access to home country government support and low-cost capital, EMNEs can achieve strategic-asset seeking OFDI by purchasing available assets through M\&As (Deng, 2009; Luo et al., 2010; Wei, 2010). Acquisitions of foreign brand and local technology enable EMNEs to overcome the liabilities of origin so that they can compete with advanced economy MNEs (Madhok \& Keyhani, 2012). Purchases of local firms' resources help EMNEs' foreign subsidiaries to reduce reliance on the HQs' FSAs and become less integrated with parent firms. In essence, EMNEs' foreign subsidiaries use home country government support and assistance as an 
alternative solution to overcome their parent firms' competitive disadvantages. Thus, we predict that:

Hypothesis 1a: An EMNE's foreign subsidiary, whose parent firm receives greater home country government support towards OFDI, will be characterized by lower global integration strategy.

Foreign subsidiaries need to develop and/or to acquire new FSAs and adapt their operations to local environments to gain the benefits of local responsiveness (Bartlett \& Ghosbal, 1989; Prahalad \& Doz, 1987; Rugman \& Verbeke, 1992, 2001). Moreover, local responsiveness strategy emphasizes the combination of new FSAs creation with host CSAs (Birkinshaw \& Hood, 1998; Meyer et al., 2011; Nguyen \& Rugman, 2015a, 2015b). However, such combination is very difficult to achieve, since host country resource endowments are monopolized by local firms and are not freely accessible (Hennart, 2009, 2012; Rugman et al., 2014). Previous studies show that EMNEs' foreign subsidiaries generally fail to tap into host CSAs and to respond to local environments, due to their limited internationalization experience, weak strategic planning, and ineffective relationships with host country stakeholders (Fan et al., 2008; Fan \& Zhu, 2014; Luo \& Tung, 2007; Wang et al., 2014).

Home country government support provides EMNEs (especially those firms from China) with extra resources, which may pave the way for them to take risks abroad (Buckley et al., 2010; Luo \& Tung, 2007). This reduces subsidiary managers' perceptions on competitive disadvantages of their parent firms, and enables them to overcome uncertainties associated with local responsiveness strategy in foreign markets. In other words, home country government support may help subsidiary managers feel more confident in pursuing local responsiveness strategy and in adapting 
to local business requirements (Lu et al., 2014; Wang et al., 2012). Therefore, we predict that:

Hypothesis 1b: An EMNE's foreign subsidiary, whose parent firm receives greater home country government support towards OFDI, will be characterized by greater local responsiveness strategy.

3.2. Moderating effects of state ownership on the relationship between home country government support and the global integration and local responsiveness strategy of the subsidiary

We argue that the effects of home country government support on the global integration strategy of the subsidiary are contingent upon the degree of state ownership of the parent firm for two key reasons. First, state-owned enterprises (SOEs), especially in the case of Chinese SOEs, have privileged access to valuable government-controlled resources, such as cheap financing, low tax rates, and public $R \& D$, which are not available to other types of companies (Deng, 2009; Hong et al., 2015; Morck et al., 2008; OECD, 2008; Xu \& Zhang, 2008). Since 2000, Chinese government has actively supported the globalization of SOEs as they are "national champions" (Liang et al., 2015). In contrast, it was not until 2003 that private enterprises in China were formally allowed to invest abroad with a very limited scale (Alon, 2010; Wei, 2010). Consequently, foreign subsidiaries of Chinese SOEs tend to perceive government support as a type of FSAs embedded in their parent firms, which are closely related to the state-ownership nature and tightly intertwined with home country institutions (home CSAs).

Second, Chinese SOEs are more likely to perceive government support as signal of political control and intervention, given that the government is the company owner 
(Duanmu, 2014; Shi, Markoczy, \& Stan, 2014). They are required to fulfill national objectives in their internationalization, such as securing energy supply and enhancing domestic firms' innovation capabilities (Duanmu, 2014; Globerman \& Shapiro, 2009; Wang et al., 2012). Thus, the global integration strategy assures that foreign subsidiaries' activities are directed towards achieving the main objectives of the HQs (Chang \& Taylor, 1999; Thite, Wilkinson, \& Shah, 2012). In other words, foreign subsidiaries are deeply embedded in the internal networks, in which parent firms maintain high degree of control in foreign operations and implement centralized organizational structure (Harzing, 2000; Westney \& Zaheer, 2009). Taken our theoretical arguments altogether, we predict that

Hypothesis 2a: The negative effect of home country government support on the global integration strategy of an EMNE's subsidiary is weakened with greater state ownership of the parent firm.

The degree of state ownership moderates the effect of home country government support on the local responsiveness strategy of EMNEs' subsidiaries. First, Chinese SOEs are often viewed as extremely inefficient and ineffective in converting home country government support into proprietary FSAs and in achieving superior financial performance results (Chen \& Tan, 2013; Cornett, Guo, Khaksari, \& Tehranian, 2010). Although they have greater access to government resources than firms without state ownership, Chinese SOEs' return on assets (ROA) are about half of their non-state counterparts and the debt-to-equity ratio is 1.6 compared to 0.8 for private firms (The Economist, 2014, 2015). The poor performance of SOEs is due to pressures to achieve political goals beyond economic rationalities, government intervention, and a lack of transparency in business practices (Buckley, 2014; Chen \& Tan, 2013; Delios, Zhou, 
$\& \mathrm{Xu}, 2008)$. Consequently, home country government support is less effective in helping foreign subsidiaries of SOEs to attain local adaptation and build local legitimacy in foreign markets.

Second, state ownership increases the liabilities of origin of EMNEs' foreign subsidiaries, because they are associated with a negative image of bureaucratic and inefficient operations relative to private and foreign enterprises (Meyer et al., 2014; OECD, 2009). State ownership may raise skepticism and hostility against EMENs' foreign subsidiaries, which are viewed as agents to implement political and economic ambitions of their home country governments (Rugman et al., 2014). Accordingly, their foreign subsidiaries may encounter greater uncertainties in accessing complementary resources in host countries and in achieving local responsiveness strategy (Cui \& Jiang, 2012; Morck et al., 2008; Rugman et al., 2014). Hence, the effect of home country government support in facilitating subsidiaries' local responsiveness strategy is likely less significant for EMNEs with greater state ownership. Thus we predict that:

Hypothesis 2b: The positive effect of home country government support on the local responsiveness strategy of an EMNE's subsidiary is weakened with greater state ownership of the parent firm.

3.3. Domestic institutional weaknesses and the global integration and local responsiveness strategy of the subsidiary

Competitive disadvantages of EMNEs originate from their domestic institutional weaknesses, which impede EMNEs to develop FSAs in their home countries (Khanna \& Palepu, 2010; Luo \& Wang, 2012). Formal institutional voids, such as weak intellectual property rights and ineffective legal frameworks, discourage firms to invest in $\mathrm{R} \& \mathrm{D}$, develop technological capabilities, and build global brands 
(Luo \& Tung, 2007; Nolan, 2005). Informal institutional hazards, such as corruption, moral degradation, government intervention, and local protectionism impede firms to develop managerial capabilities and improve corporate governance practices (Boisot \& Meyer, 2008; Wang et al., 2014).

Domestic institutional weaknesses push EMNEs to invest in more efficient and transparent institutional environments, where they can concentrate on generating new knowledge and developing their competitive advantages (Wei, 2010; Witt \& Lewin 2007). In other words, EMNEs' foreign subsidiaries may become less integrated with parent-level resources and the HQs' organizational culture which is deeply rooted in home country institutional deficiencies. Therefore, we suggest that:

Hypothesis 3a: An EMNE's foreign subsidiary, which perceives greater domestic institutional weaknesses, will be characterized by lower global integration strategy.

Because of domestic institutional weaknesses, EMNE parent firms are unable to build global reputation and develop advanced technology. In order to compensate for competitive disadvantages and survive in foreign markets, EMNEs' foreign subsidiaries need to develop new strategic resources and build their own reputation and legitimacy in local operations (Luo \& Tung, 2007; Wang et al., 2014).

Domestic institutional weaknesses also have psychological consequences for EMNEs' subsidiary managers in the form of either self-doubt or unawareness of the firms' true potential in international competition and shift their emphasis on foreign operations (Bartlett \& Ghosbal, 2000). Foreign subsidiaries need to develop FSAs through local adaptation as they are impelled to increase credibility within EMNEs (Deng, 2009; Rui \& Yip, 2008; Wang et al., 2014). Hiring managers from host countries enable EMNEs' foreign subsidiaries to build local credibility and distance themselves 
from the unfavorable image of their parent firms (Bartlett \& Ghosbal, 2000; Wang et al., 2014). Therefore, we predict that:

Hypothesis 3b: An EMNE's foreign subsidiary, which perceives greater domestic institutional weaknesses, will be characterized by greater local responsiveness strategy.

3.4. Moderating effects of state ownership on the relationship between domestic institutional weaknesses and the global integration and local responsiveness strategy of the subsidiary

On the one hand, state ownership might compensate for the negative effects of domestic institutional weakness because SOEs can achieve market power based on the access to government resources and the benefits of preferential treatment (Boisot \& Meyer, 2008; Luo et al., 2010; Meyer et al., 2014). For example, Chinese SOEs often have in-house research institutes and government-funded $R \& D$ investments because they are considered as major actors in the national innovation system (OECD, 2008; $\mathrm{Xu} \&$ Zhang, 2008). This may offset their foreign subsidiaries' perceptions toward competitive disadvantages resulting from inefficient domestic R\&D systems and weak intellectual property protection rights.

On the other hand, domestic institutional hazards may not be a matter of concerns for state-owned EMNEs due to their inherent organizational culture and corporate governance. For example, Chinese SOEs often sacrifice economic goals in favor of interests of the state. They are controlled by multiple levels of government authorities, which result in a lack of accountability and transparency. Thus, agency problems are particularly profound in Chinese SOEs (Chen \& Young, 2010; Globerman \& Shapiro, 2009; Liu \& Tylecote, 2009). This is a type of administrative heritage of 
Chinese SOEs. Consequently, foreign subsidiaries of state-owned EMNEs do not perceive institutional hazards really a big problem. Thus, we hypothesize:

Hypothesis 4a: The negative effect of domestic institutional weaknesses on the global integration strategy of an EMNE's foreign subsidiary is weakened with greater state ownership of the parent firm.

Domestic institutional weaknesses push foreign subsidiaries to access host CSAs in developing new resources through local responsiveness strategy. This will assure their survival and growth in the intensified competition with local firms and other global giants in foreign markets. In other words, local responsiveness strategy is assumed to be mainly driven by the economic considerations of performance and profit maximization.

However, Chinese SOEs' foreign subsidiaries often carry out the ultimate goals of home country government in achieving a broader scope of national-level objectives (Globerman \& Shapiro, 2009; Pan et al., 2014). The political purposes of Chinese OFDI often outweigh the economic purposes (Buckley et al., 2007; Cuervo-Cazurra, Inkpen, Musacchio, \& Ramaswamy, 2014; Duanmu, 2014). Furthermore, Chinese SOEs are not under pressure of dividend payments to their majority shareholders-the state, and threats of bankruptcy for poor financial performance (Chen \& Young, 2010; Globerman \& Shapiro, 2009; Luo et al., 2010; Zhang \& Freestone, 2013). Therefore, they are less motivated to improve their competitive disadvantages and to catch up with global competitors.

The above discussion suggests that SOEs and their foreign subsidiaries tend to downplay the importance of economic objectives in their internationalization and thus make less effort to compensate for domestic institutional weaknesses by taking 
initiatives and creating new FSAs through local responsiveness strategy. Thus, we predict that:

Hypothesis 4b: The positive effect of domestic institutional weaknesses on the local responsiveness strategy of an EMNE's foreign subsidiary is weakened with greater state ownership of the parent firm.

The direct effects of home country government support and domestic institutional weaknesses, and the moderating effects of state ownership on global integration and local responsiveness of Chinese multinational subsidiaries are depicted in Figure 1.

Insert Figure 1 here

\section{Methodology}

\subsection{Research context, data sources, sample and questionnaire design}

We test our hypotheses using a self-constructed dataset of foreign subsidiaries of the top 500 Chinese manufacturing firms, published by the China Enterprise Confederation and China Enterprise Directors Association. We only focus on manufacturing Chinese firms since service OFDI still accounts for only a small fraction of China's total OFDI (Wang et al., 2014). We compiled a list of Chinese multinational subsidiaries from multiple sources. These included firms' annual reports, announcements on the establishment of new subsidiaries, stock market documents (e.g., prospectuses, share issues, and various announcements), websites of Chinese firms and their foreign subsidiaries. We had a total population of 633 foreign subsidiaries, which belong to 144 Chinese manufacturing MNEs investing in 78 countries from 1991 to 2010. 
We carefully designed our questionnaire survey which was based on international business (IB) theories. We self-designed questions of home country government support and domestic institutional weaknesses because these two variables are new in the literature of EMNEs and their subsidiaries. They were grounded in the home country institution-based view and prior research on Chinese OFDI (Deng, 2009; Luo \& Tung, 2007; Luo et al., 2010; Morck et al., 2008; Wei, 2010). Other questions were adapted from previous empirical studies on subsidiary strategies (Bartlett \& Ghoshal, 1989; Kim \& Hwang, 1992; Luo, 2001). We had our survey instrument reviewed by several accomplished profound senior scholars in the field of IB, especially those conducting research on subsidiary strategy and management.

We pre-tested our questionnaires by telephone interviews with eight subsidiaries, which belong to three Chinese MNEs located in Zhejiang province and they are included in our final sample. These subsidiary managers provided useful feedback and suggestions and we revised our questionnaire accordingly. These include (1) statements in each question should be shorter and simpler; (2) plain language should be used instead of academic terminologies; (3) questions for several variables which were adopted from the literature were revised to avoid confusion. These careful procedures assured that our questionnaire was easy to understand and to respond. The specific questions used in this study are presented in Table 1 with detailed assessment of construct reliability and construct validity.

\section{Insert Table 1 here}

Our unit of analysis was Chinese multinational subsidiaries and the most desirable informants were subsidiary managers. According to our pre-test interviews, subsidiary managers who were closely involved in the process of establishment of 
foreign subsidiaries were familiar with home country institutions. To ensure the reliability of our survey data, we targeted the following informants:

1) the respondent was a member of the top management team (i.e. either a managing director or a general manager).

2) the investment project was completed by 2010 .

3) the respondent has been involved in the establishment process of the subsidiary.

We manually collected information on subsidiary management team and the contact information from multiple sources. These include information in annual reports, websites of parent firms and foreign subsidiaries, business news, professional networks such as LinkedIn, and other public sources. We approached subsidiary managers by emails to invite them to participate in the survey. We also sent our questionnaires to subsidiary managers by post when we could not find their email address information. We collected data over a period of seven months from September 2011 to March 2012. We contacted all 633 subsidiaries. After two rounds of invitation and five rounds of friendly reminders, we received 124 complete and valid responses. Our survey achieved a response rate of 19.6 percent, comparable favourably to that of previous studies focusing on subsidiary managers (e.g., Harzing, 2002: 20.0 percent; Luo, 1999: 19.2 percent; Nguyen \& Rugman, 2015a, 2015b: 20 percent).

The sample size is sufficient for our empirical tests for two reasons. First, according to Bartlett, Kotrlik, \& Higgins (2001), a sample size of 124 respondents is enough for a total population of 633 foreign subsidiaries required for continuous data. Second, the ratio of observations to independent variables should not fall below five for multiple regression analysis in order to ensure the results are not too specific to the sample (Hair, Black, Babin, \& Anderson, 2010). Therefore, the sample is statistically 
sufficient given that there are eleven variables (including control variables) in this study.

Table 2 presents the data characteristics of our sample subsidiaries and their parent firms. The 124 participating subsidiaries belong to 118 Chinese parent firms. In terms of entry modes, 65 percent of sample subsidiaries are established by greenfields and 35 percent by acquisitions. In terms of ownership, 59 percent are wholly owned foreign subsidiaries (WFOEs) and 41 percent are joint ventures (JVs). Subsidiaries of state-owned parent firms account for 41 percent and of non-state owned parent firms for 59 percent. In terms of geographic dispersion, 62 percent of these subsidiaries are located in developed countries (25 percent in the United States, 19 percent in Europe, 6 percent in Oceania and 12 percent in other regions), and 38 percent of the sample subsidiaries are established in developing countries (27 percent in Asia, 8 percent in Africa and 3 percent in others).

Insert Table 2 here

\subsection{Non-response bias test}

To estimate the likelihood of a non-response bias, we compared data characteristics of respondents and non-respondents, which we collected these data from parent firms' annual reports. We used the chi-square test for categorical variables and the t-test for continuous variables. The results show that there are no differences between the respondents and non-respondents at a 5 percent significance level, in terms of equity ownership (WFOE versus JV: $x^{2}=3.42, p=.18$ ), establishment modes (greenfield versus acquisition: $x^{2}=0.14, p=.71$ ), host country (developing versus developed: $\left.x^{2}=0.02, p=.90\right)$, the degree of state ownership $(t=0.88, p=.38)$, and investment size $(t=-0.62, p=.54)$. 
Meanwhile, we used a time trend extrapolation test following Armstrong \& Overton (1977) who argue that late respondents tend to represent non-respondents. We compare the above characteristics between early respondents and late respondents. The early respondents included all those who filled in the questionnaire promptly after they had received our e-mails from the first two rounds of invitations, whereas the late-respondent group consisted of those who responded following the last two rounds of reminders. There are no significant differences between early and late respondent groups with the above characteristics.

Since the decision to response or not response our questionnaire was made by individual informants, so the final sample is a self-selected and not a random sample. Therefore, we applied the Heckman correction procedure (Heckman, 1979) with a twostep statistical approach to check if there is a selection bias. This approach has been used by other studies checking the non-response bias (Lepak, Takeuchi \& Snell, 2003; Pérez-Nordtvedt, Babakus \& Kedia, 2010). Baruch \& Holtom (2008) argue that individuals are more likely to respond to questionnaire if they are from a low power distance country and receive questionnaire through email (compared to traditional mail). We introduced these two new variables that influence whether an informant responded to our questionnaire in the Heckman selection equation, since all the other variables (equity ownership, establishment modes, state ownership, host country development and investment size) are included in the initial model for integration and local responsiveness. We find that the value for the calculated inverse Mills ratio (IMR) is not statistically significant. We report and discuss the hypothesis results in Section 5 by including IMR as one control variable. We also compare the results for independent variables and moderating effects with the results generated without the inclusion of 
IMR, and the values remain the same. Therefore, we conclude that non-response bias is not a serious problem in this study.

\subsection{Common method variance}

The best strategy to avoid potential common method variance is to collect information for dependent and independent variables from different sources (Chang, Witteloostuijn, \& Eden 2010). In addition to the survey data, we constructed one independent variable (state ownership) and several control variables (subsidiary size, establishment mode, equity ownership, and host country development) by using information from parent firms' annual reports and country-level public data source (World Bank country classification). The parent firms are publicly listed and are required to disclose information and data.

In addition, we also implemented a number of ex-ante and ex-post procedures suggested by Chang et al., (2010) and Podsakoff, MacKenzie, Lee, \& Podsakoff (2003). First, in the ex-ante procedures, we assured respondents of complete confidentiality. We used multi-item constructs, and scale items of interest were spread throughout the questionnaire. Furthermore, the survey asked a broad range of issues on Chinese OFDI, which went beyond this study's focus. Dependent and independent variables appeared in different parts of the questionnaire, which created a psychological separation for the respondents (Podsakoff et al., 2003).

Second, in the ex-post procedures, we specified a complex model that includes moderating effects, since such complicated relationships are not a part of the respondents' theory-in-use (Chang et al., 2010). Moreover, we applied the statistical remedy, which includes Harman's one-factor test (Podsakoff \& Organ, 1986). A principle component analysis showed that the largest factor explains only 18.4 percent 
of the total variance in the analysis. Thus, our results are not subject to a common method bias in the survey responses.

\subsection{Variable measurements}

\subsubsection{Dependent variables}

The scale used for the dependent variables in the survey is provided in Table 1. Global integration emphasizes the support and resource sharing between parent MNEs and their foreign subsidiaries (Bartlett \& Ghoshal, 1989; Kobrin, 1991; Mauri \& Phatak, 2001). We use the construct developed by Kim \& Hwang (1992), in which a subsidiary's global integration is measured by subsidiary managers' perceptions toward sharing with Chinese parent firms' resources in seven areas after foreign entry. We use a 7-point Likert scale (1=not at all to $7=$ very much).

We follow Luo (2001), in which the construct of local responsiveness is measured as subsidiary managers' perceptions towards responses to local customer needs, government policies, market conditions, and rivalries using a 7-point Likert scale (1=not at all to $7=$ very much).

\subsubsection{Independent variables}

Respondents evaluate home country government support during subsidiary establishment on a 7 -point Likert scale (1=not at all to $7=$ very much), in terms of financial support, the gathering of intelligence data and information, privileged access to domestic resources, and risk-safeguard mechanisms.

Domestic institutional weaknesses is measured by subsidiary managers' perceptions toward OFDI as the strategy to escape from China's institutional deficiencies using a 7 -point Likert scale (1=not at all to $7=$ very much). This includes 
imperfect capital markets, weak intellectual property rights and legal frameworks, and decentralization of economic and political administration.

We measured the nature of state ownership in Chinese parent firms by the percentage of equity ownership by the Chinese government and its agencies. This measurement has been widely used by previous studies (Cui \& Jiang, 2012; Wang et al., 2012). Our data is sourced from parent firms' annual reports.

\subsubsection{Control variables}

We control for subsidiary size, which is measured by the ratio of financial investment of the subsidiary to the parent firm's total global assets (Brouthers \& Brouthers, 2000; Slangen \& Hennart, 2008). Data is sourced from parent firms' annual reports.

Subsidiary's establishment mode is a dummy variable with acquisitions coded as " 1 " and greenfields coded as " 0 ". Data is sourced from parent firms' annual reports. A newly established subsidiary is more likely to adopt the strategy of global integration, while an acquired subsidiary is inclined to take a locally responsiveness strategy (Harzing, 2000, 2002; Slangen \& Hennart, 2007).

Equity ownership is measured by using the dummy variable "1" for WFOSs with more than $95 \%$ equity controlled by Chinese parent firms, and " 0 " for JVs. Data is sourced from parent firms' annual reports.

Competition leads to a high level of local responsiveness by requiring subsidiaries to focus on product differentiation specific to local environment, and maintain good relationships with local stakeholders (Luo, 2001). Respondents selfassess local competition in host markets with respect to existing rivals and new entrants based on a 7 -point Likert scale (1=not at all to $7=$ very much). 
Demand heterogeneity makes it more difficult and less efficient to globally leverage resources and manage dispersed international operations (Doz \& Prahalad, 1991). In contrast, differences in demands across host countries require a high degree of product differentiation and local adaption (Luo, 2001; Roth \& Morrison, 1990). Demand heterogeneity is measured by a pair of questions concerning diversity and segmentation with a 7-point Likert scale (1=not at all to 7=very much) (Luo, 2001).

We controlled for host country economic development by following classification of the World Bank. We use a dummy variable with developed country coded as " 1 " and developing country coded as "0". Finally, we control for the potential effect of different manufacturing sectors on subsidiary strategy by using primary metal as the baseline industry.

\subsection{Reliability and validity of construct assessment}

We assess the reliability of six multi-item constructs with Cronbach's alpha. A value of 0.70 is the cut-off point of a satisfactory internal consistency (Field, 2009; Hair et al., 2010). As shown in Table 1, Cronbach's alpha ranges from 0.767 to 0.856 , indicating that the scale items of our constructs are reliable.

We evaluate construct validity by examining convergent and discriminant validity. The confirmatory factor analysis (CFA) model provides a good overall fit of the data $\quad$ (Chi-square $=346.458 ; \quad$ CMIN/DF=2.203; NFI=0.930; CFI=0.974; RMSEA=0.072). As shown in Table 1, all individual items load strongly, which are much greater than the recommended value of 0.50 and they are statistically significant (Fornell \& Larcker, 1981; Hair et al., 2010). This indicates that they converge on a common underlying construct. 
We also assess six constructs for discriminant validity by calculating the square root of the average variance extracted (AVE) (see Table 1). The value of the square root of AVE estimates for each construct is significantly greater than any correlation among pairs of constructs. Therefore, the constructs demonstrate adequate discriminant validity (Fornell \& Larcker, 1981).

\section{Results}

\subsection{Hypotheses tests and results}

Table 3 presents the descriptive statistics of all variables and their correlations.

\section{Insert Table 3 here}

All correlations between pairs of independent variables are lower than 0.3 , which is below the threshold of 0.5 (Hair et al., 2010). The analysis for Variance Inflation Factor (VIF) and Tolerance shows that the largest VIF value is 1.942 and the lowest Tolerance Value is 0.705 . Hence, there is no sign of multicollinearity in our dataset. Furthermore, we make all interaction terms to be mean-centred to avoid potential multicollinearity problems (Cui \& Jiang, 2012; Wang et al., 2012).

We test our hypotheses using ordinary least square (OLS) estimates (by having the IMR as one control variable). We use two separate sets of models (each including control variables, independent variables, and the moderator) to test hypotheses for global integration and local responsiveness, as reported in Table 4 and Table 5 respectively. We analyze four models for each dependent variable and the F-statistics indicates that all of them are significant.

As shown in Table 4, Model 1 includes control variables and state ownership. Three of the control variables (establishment mode, equity ownership and demand heterogeneity) are significant. State ownership of Chinese parent firms is positively and 
significantly associated with subsidiaries' global integration strategy $(\mathrm{p}<0.05)$.

\section{Insert Table 4 here}

Model 2 includes two independent variables. The result $(\mathrm{p}<0.01)$ supports Hypothesis 1a, which indicates that Chinese multinational subsidiaries perceive home country government support as a source of compensation for their lack of traditional Western-type FSAs, so that they can overcome the liabilities of foreignness by integrating less with their parent firms. The results illustrate that Hypothesis $3 \mathrm{a}$ is supported $(\mathrm{p}<0.05)$ indicating the greater the domestic institutional imperfections perceived by subsidiary managers, the weaker the global integration strategy will be.

In Model 3, Hypothesis 2a is not supported since the moderating effect of state ownership on the relationship between government support and global integration is insignificant. The results support Hypothesis $4 \mathrm{a}(\mathrm{p}<0.05)$, which suggests that subsidiaries of Chinese MNEs with greater degree of state ownership are not willing to overcome domestic institutional deficiencies by disintegrating from their parent firms. However, the global integration strategy in the case of Chinese SOEs is purely driven by political orientations, especially in accessing government resources and maintaining consistency with political objectives (Deng, 2009; Luo \& Tung, 2007; Wang et al., 2012). These types of advantages associated with state ownership are deeply rooted in China's institutions, which are difficult to be transferred internationally (Rugman et al., 2016). Finally, the results are robust in Model 4 (full model), which includes all independent variables and moderating effects. The adjusted $R^{2}$ value $(0.344)$ for the full model is higher than the other models.

Table 5 provides the regression results for local responsiveness strategy. Three control variables in the baseline Model 1 are significant (establishment mode, demand heterogeneity, and host country economic development). Meanwhile, subsidiaries of 
Chinese MNEs with higher state ownership are not actively responsive to local conditions $(\mathrm{p}<0.01)$. In Model 2, no significant relationship is observed between government support and subsidiary strategy of local responsiveness. Therefore, Hypothesis $1 \mathrm{~b}$ is not supported. In contrast, domestic institutional weaknesses push foreign subsidiaries to pursue local responsiveness strategy $(\mathrm{p}<0.001)$. Therefore Hypothesis $3 b$ is supported.

\section{Insert Table 5 here}

In Model 3 with moderating effects, Hypothesis $2 b$ is not supported, as the coefficient estimate is insignificant. In contrast, Hypothesis $4 \mathrm{~b}$ is supported as state ownership negatively moderates the impact of domestic institutional weaknesses on the subsidiary strategy of local responsiveness $(\mathrm{p}<0.05)$. This is undesirable because Chinese SOEs face even greater liabilities of origin due to their bureaucratic nature, weak corporate governance and poor operating efficiency (Chen \& Young, 2010; Globerman \& Shapiro, 2009). However, their foreign subsidiaries are not motivated to pursue local responsiveness strategy as responses to domestic institutional deficiencies due to rigidity coming from the direct consequence of state ownership nature. Additionally, Model 4 which includes all variables shows unchanged results and improves explanatory power.

Figure 2 illustrates the moderating effects of state ownership.

$$
\text { Insert Figure } 2 \text { here }
$$

\subsection{Robustness tests}

We perform robustness tests and validate our results with resampling techniques, which are powerful tools for estimating standard errors in small samples. These include bootstrap standard errors and statistical tests from the average of the 
statistics from the bootstrap samples. We also split the dataset into two random sample groups and compare the results, which are consistent (Efron, 1983).

To address endogeneity concerns, we conduct a Hausman test by comparing the OLS estimates with two-stage least squares (2SLS) estimates. We use region-specific marketization developed by Fan, Wang, \& Zhu (2006) as the instrumental variable (IV) for domestic institutional weaknesses, since uncertainties and transaction cost associated with weak institution and government interruption tend to be lower in regions with a higher level of marketization (Luk, Yau, Sin, Tse, Chow, \& Lee, 2008). We identify the encouraged OFDI industries (Hong et al., 2015) and government financial grant toward Chinese parents as appropriate IVs for government support in OFDI. A valid IV should be correlated with the independent variables, but uncorrelated with the error term (Cameron \& Trivedi, 2005). We conduct the over-identifying restrictions test and perform a regression of the IV residuals. The results of 2SLS estimation are consistent with those of OLS analysis, showing that endogeneity is not a concern in the key variables. Due to space constraints, our 2SLS results are not reported.

\section{Discussion and conclusion}

\subsection{Theoretical contributions}

This study enhances our understanding of the I/R framework in the context of EMNEs' foreign subsidiaries. Bartlett \& Ghoshal (1989) use case studies of nine MNEs from advanced economies (the United States, Europe, and Japan) to develop the transnational solution, in which an MNE maintains high integration and resource coordination within MNE network, and requires subsidiaries simultaneously to actively response to local business environments and customer preferences. Transnational 
solution is perceived as the highest strategic solution since it is built upon multiple sources of competitive advantages, including parent-firm FSAs developed in home countries and subsidiary-generated FSAs through accessing host CSAs (Rugman \& Verbeke, 1992, 2001, 2003; Rugman et al., 2011; Rugman \& Nguyen, 2014).

However, we find that home country institutions of EMNEs do not stimulate foreign subsidiaries to achieve twin goals of global integration and local responsiveness simultaneously. This may raise concerns about EMNEs' internationalization strategies. First, subsidiaries tend to disintegrate with their parent firms due to domestic institutional deficiencies and a lack of FSAs developed by EMNEs in home countries. In other words, subsidiary strategy of global integration is constrained by their home country institutions. It is important for emerging economies to improve domestic institutional environments, so that EMNEs are more confident to rely on home CSAs to develop core FSAs.

Second, EMNEs' foreign subsidiaries tend to adopt a multinational strategy (also known as multi-domestic strategy) with low global integration (Hypothesis 3a) and high local responsiveness (Hypothesis 3b) as a response to weak domestic institutions. In other words, the success of EMNEs' foreign operations largely depend upon their subsidiaries taking initiatives to develop competitive advantages by accessing host CSAs and responding to local market requirements. However, given that host country resources are monopolized by local firms and are not freely accessible to foreign investors, local responsiveness is often difficult to achieve (Hennart, 2009, 2012).

It is prevalent for EMNEs to purchase global brands and advanced technology in order to overcome the liabilities of origin, enhance their reputation, and achieve local adaptation. However, the major challenge for EMNEs is that with a short period of 
internationalization, they lack integration skills and systems, and international managerial expertise to integrate newly acquired assets and to coordinate worldwide activities (Peng, 2012; Rugman et al, 2016). One the one hand, government needs to devise support which helps EMNEs' foreign subsidiaries to overcome uncertainties and risks associated with local responsiveness. On the other hand, given the insignificant relationship between government support and local responsiveness in this study, subsidiaries may need to take more initiatives in exploiting government support (a type of home CSAs) in realizing local adaption in host countries.

\subsection{Implications for practice}

Our study provides important implications for EMNE managers and policy makers. It is critical to recognize the importance of subsidiary strategies for EMNEs in overcoming their parent firms' competitive disadvantages in international markets, and in contributing to the overall EMNEs' long-term strategies to improve international competitiveness. Understanding the nature and the implications of home country institutional heritage for subsidiary strategies could prepare EMNEs' subsidiary managers better for decisions on strategy and management of foreign businesses. The insights from our findings provide useful implications for policy makers, in which weak domestic institutions push EMNEs to depart from their parent firms by investing abroad. Meanwhile, government support and state ownership might enable EMNEs to embark on internationalization but such institutional incentives might not be of help for their subsidiaries' strategies in foreign markets.

\subsection{Limitations and suggestions for future research directions}

Our study is subject to several limitations. First, we use a survey dataset with Chinese multinational subsidiaries, which may raise concern on the country-specific 
nature of our findings. We suggest that future research could conduct a multiplecountry survey and compare and contrast the findings with our results. Second, subsidiary strategies are not static, but dynamic and evolving over time. However, our study is limited to the analysis from a cross-sectional data. It would be interesting to observe how foreign subsidiaries and parent firm EMNEs promote transnational solution over time. Lastly, the findings of our study are restricted to a set of the largest manufacturing MNEs. Future research can extend our work to other industries such as the service sector given that manufacturing OFDI often differs from services OFDI in terms of motives and local adaptation strategy (Brouthers \& Brouthers, 2003).

\section{Conclusions}

Our study advances the EMNE literature, moving away from the parent-centric perspectives on internationalization. We confirm the importance of home country institutions in shaping subsidiary strategies of EMNEs. We find that it is difficult for EMNEs to pursue a transnational solution due to their lack of FSAs and the liabilities of origin they suffer because of their national origins from emerging economies. Domestic institutional weaknesses force EMNEs' foreign subsidiaries to follow a multi-domestic strategy. However, the nature of state ownership of parent firms make their foreign subsidiaries unwilling to disintegrate and unmotivated to take initiatives in developing new FSAs and in responding to local conditions in foreign markets accordingly. In conclusion, our study is among the first few attempts to look into an important research area. We hope that it will prompt future research towards a more systematic understanding of EMNEs' subsidiary strategies. 


\section{References}

Alon, T. (2010). Institutional analysis and the determinants of Chinese FDI. Multinational Business Review, 18(3), 1-24.

Andersson, U., Forsgren, M., \& Holm, U. (2002). The strategic impact of external networks: subsidiary performance and competence development in the multinational corporation. Strategic Management Journal, 23(11), 979-996.

Armstrong, J. S., \& Overton, T. S. (1977). Estimating nonresponse bias in mail surveys. Journal of Marketing Research, 14(3), 396-402.

Baruch, Y., \& Holtom, B.C. (2008). Survey response rate levels and trends in organizational research. Human Relations, 61(8): 1139-1160.

Bartlett, C. A., \& Ghosbal, S. (1989). Managing across borders: The transnational solution. Boston: Harvard Business School Press.

Bartlett, C. A., \& Ghoshal, S. (2000). Going global: Lessons from late movers. Harvard Business Review, 78(2), 132-142.

Bartlett, J. E., Kotrlik, J. W., \& Higgins, C. C. (2001). Organizational Research: Determining Appropriate sample Size in Survey Research. Information Technology, Learning, and Performance Journal, 19(1), 43-50.

Birkinshaw, J. M. (1995). Taking the initiative: Value-added strategies for Canadian subsidiaries. Business Quarterly, 59(4), 97-102.

Birkinshaw, J. M. (1996). How subsidiary mandates are gained and lost. Journal of International Business Studies, 27(3), 467-496.

Birkinshaw, J. M. (1997). Entrepreneurship in multinational corporations: the characteristics of subsidiary initiative. Strategic Management Journal, 18(3), 207-229. 
Birkinshaw, J. M., \& Hood, N. (1998). Multinational subsidiary evolution: Capability and charter change in foreign-owned subsidiary companies. Academy of Management Review, 23(4), 773-795.

Birkinshaw, J. M., \& Morrison, A. J. (1995). Configurations of strategy and structure in subsidiaries of multinational corporations. Journal of International Business Studies, 26(4), 729-754.

Birkinshaw, J. M., \& Pedersen, T. (2009). Strategy and management in MNE subsidiaries. In A. M. Rugman (Eds.), The Oxford handbook of international business (pp. 367-388). New York: Oxford University Press.

Boisot, M., \& Meyer, K. W. (2008). Which way through the open door? Reflections on the internationalization of Chinese firms. Management and Organization Review, 4(3), 349-366.

Brouthers, K. D., \& Brouthers, L. E. (2000). Acquisition of greenfield start-up? Institutional, cultural and transaction cost influences. Strategic Management Journal, 21(1), 89-97.

Brouthers, K. D., \& Brouthers, L. E. (2003). Why service and manufacturing entry mode choices differ: The influence of transaction cost factors, risk and trust. Journal of Management Studies, 40(5), 1179-1204.

Buckley, P. J. (2014). Forty years of internalization theory and the multinational enterprise. Multinational Business Review, 22(3), 227-245.

Buckley, P. J., Clegg, J. L., Cross, A. R., Liu, X., Voss, H., \& Zheng, P. (2007). The determinants of Chinese outward foreign direct investment. Journal of International Business Studies, 38(4), 499-518.

Buckley, P. J., Clegg, J. L., Cross, A. R., \& Voss, H. (2010). What can emerging markets learn from the outward direct investment policies of advanced economies? In 
K. Sauvant, W. Maschek, \& G. McAllister (Eds.). Foreign direct investment from emerging markets: The challenges ahead (pp. 243-276). London: Palgrave Macmillan. Cameron, A. C., \& Trivedi, P. (2005) Microeconometrics: Methods and Applications. New York: Cambridge University Press.

Cantwell, J. A., \& Mudambi, R. (2005). MNE competence-creating subsidiary mandates. Strategic Management Journal, 26(12), 1109-1128.

Chang, E., \& Taylor, S. M. (1999). Control in multinational corporations (MNCs): The case of Korean manufacturing subsidiaries. Journal of Management, 25(4), 541-566.

Chang, S. J., Witteloostuijn, A., \& Eden, L. (2010). From the editors: Common method variance in international business research. Journal of International Business Studies, 41(2), 178-184.

Chen, Z. X., \& Tan, K. H. (2013). The impact of organization ownership structure on JIT implementation and production operations performance. International Journal of Operations \& Production Management, 33(9), 1202-1229.

Chen, Y. Y., \& Young, M. N. (2010). Cross-border mergers and acquisitions by Chinese listed companies: A principal-principal perspective. Asia Pacific Journal of Management, 27(3), 523-539.

Cornett, M. M., Guo, L., Khaksari, S., \& Tehranian, H., (2010). The impact of state ownership on performance differences in privately-owned versus state-owned banks: An international comparison. Journal Financial Intermediation, 19, 74-94.

Cuervo-Cazurra A., Inkpen, A., Musacchio, A., $\quad \& \quad$ Ramaswamy, $\quad$ K. (2014). Governments as owners: State-owned multinational companies. Journal of International Business Studies, 45(8), 919-942. 
Cui, L., \& Jiang, F. (2012). State ownership effect on firms? FDI ownership decisions under institutional pressure: A study of Chinese outward investing firms. Journal of International Business Studies, 43(3), 264-284.

Delios, A., Zhou, N., \& Xu, W. W. (2008). Ownership structure and the diversification and performance of publicly-listed companies in China. Business Horizons, 51(6), 473-483.

Deng, P. (2009). Why do Chinese firms tend to acquire strategic assets in international expansion? Journal of World Business, 44(1), 74-84.

Doz, Y. L., \& Prahalad, C. K. (1991). Managing MNCs: A search for a new paradigm. Strategic Management Journal, 12 (Special Issue 1): 145-164.

Duanmu, J. (2014). State-owned MNCs and host country expropriation risk: the role of home state soft power and economic gunboat diplomacy. Journal of International Business Studies, 45(8), 1044-1060.

Efron, B. (1983), Estimating the error rate of a prediction rule: Some improvements on cross-validation. Journal of the American Statistical Association, 78(3), 16-331.

Fan, D., Nyland, C., \& Zhu, J. H. (2008). Strategic implications of global integration and local responsiveness for Chinese multinationals: An area for future study. Management Research News, 31(12), 922-940.

Fan, D., \& Zhu, J. H. (2014) How do Chinese multinationals perceive factors affecting the integration-responsiveness framework? International Journal of Emerging Markets, 9(2), 181-204.

Fan, G., Wang, X. L., \& Zhu, H. P. (2006). The Report on the Relative Process of Marketization of Each Region in China. Beijing: Economic Science Publishing House. Field, A. P. (2009). Discovering statistics using SPSS. London: Sage publications. 
Fornell, C., \& Larcker, D. F. (1981). Evaluating structural equation models with unobservable variables and measurement error. Journal of Marketing Research, 18 (1), $39-50$.

Garcia-Pont, C., Canales, J. I., \& Noboa, F. (2009). Subsidiary strategy: The embeddedness component. Journal of Management Studies, 46(2), 182-214.

Globerman, S., \& Shapiro, D. M. (2009). Economic and strategic considerations surrounding Chinese FDI in the United States. Asia Pacific Journal of Management, 26(1), 163-183.

Hair, J., Black, W. C., Babin, B. J., \& Anderson, R. E. (2010). Multivariate data analysis (7th ed.). Upper saddle River, New Jersey: Pearson Education International. Harzing, A. W. (2000). An empirical analysis and extension of the Bartlett and Ghoshal typology of multinational companies. Journal of International Business Studies, 31(1), 101-120.

Harzing, A. W. (2002). Acquisitions versus greenfield investments: International strategy and management of entry modes. Strategic Management Journal, 23(3), 211227.

Heckman, J. (1979). Sample selection bias as a specification error, Econometrica, 47(1), 153-61.

Hennart, J. F. (2009). Down with MNE-centric theories! Market entry and expansion as the bundling of MNE and local assets. Journal of International Business Studies, 40(9), 1432-1454.

Hennart, J. F. (2012). Emerging market multinationals and the theory of the multinational enterprise. Global Strategy Journal, 2(3), 168-187. 
Hoenen, A. K. \& Kostova, T. (2014). Utilizing the broader agency perspective for studying headquarters-subsidiary relations in multinational companies, Journal of International Business Studies, 46(1), 104-113.

Hong, J., Wang, C., \& Kafouros, M. (2015). The role of the state in explaining the internationalization of emerging market enterprises. British Journal of Management, $26(1), 45-62$.

Khanna, T., \& Palepu, K. G. (2010). Winning in emerging markets: A roadmap for strategy and execution. Boston, MA: Harvard Business Press.

Kim, W. C., \& Hwang, P. (1992). Global strategy and multinationals' entry mode choice. Journal of International Business Studies, 23(1), 29-53.

Kobrin, S. J. (1991). An empirical analysis of the determinants of global integration. Strategic Management Journal, 12(Special Issue), 17-31.

Kostova, T., \& Zaheer, S. (1999). Organizational legitimacy under conditions of complexity: The case of the multinational enterprise. Academy of Management Review, 24(1), 64-81.

Kostova, T., \& Roth, K. (2002). Adoption of an organizational practice by subsidiaries of multinational corporations: Institutional and relational effects. Academy of Management Journal, 45(1), 215-233.

Lepak, D. P., Takeuchi, R., \& Snell, S. A. (2003). Employment flexibility and firm performance: examining the interaction effects of employment mode, environmental dynamism, and technological intensity. Journal of Management. 29(5): 681-703.

Liang, H., Ren, B., \& Sun, S. L. (2015). An anatomy of state control in the globalization of state-owned enterprises. Journal of International Business Studies, 46(2): 223-240. 
Liu, J. J., \& Tylecote, A. (2009). Corporate governance and technological capability development: Three case studies in the Chinese auto industry. Industry and Innovation, 16 (4-5), 525-544.

Lu, J., Liu, X., \& Wang, H. (2011). Motives for outward FDI of Chinese private firms: Firm resources, industry dynamics, and government policies. Management and Organization Review, 7(2), 223-248.

Lu, J., Liu, X., Wright, M., \& Filatotchev, I. (2014). The impact of domestic diversification and top management teams on international diversification of Chinese firms. International Business Review, 23(2), 455-467.

Luk, C., Yau, O., Sin, L., Tse, A., Chow, R., \& Lee, J. (2008). The effects of social capital and organizational innovativeness in different institutional contexts. Journal of International Business Studies, 39(4), 589-612.

Luo, Y. (1999). Time-based experience and international expansion: The case of an emerging economy. Journal of Management Studies, 36(4), 505-534.

Luo, Y. (2001). Determinants of local responsiveness: Perspectives from foreign subsidiaries in an emerging market. Journal of Management, 27(4), 451-477.

Luo Y. (2003). Market-seeking MNEs in an emerging market: How parent-subsidiary links shape overseas success. Journal of International Business Studies, 34(3), 290309.

Luo, Y., \& Tung, R. L. (2007). International expansion of emerging market enterprises: A springboard perspective. Journal of International Business Studies, 38(4), 481-498. Luo, Y. L., Xue, Q. Z., \& Han, B. J. (2010). How emerging market governments promote outward FDI: Experience from China. Journal of World Business, 45(1), 6879. 
Luo, Y., \& Wang, S. L. (2012). Foreign direct investment strategies by developing country multinationals: A diagnostic model for home country effects. Global Strategy Journal, 2(3), 244-261.

Madhok, A., \& Keyhani, M. (2012). Acquisitions as entrepreneurship: Asymmetries, opportunities, and the internationalization of multinationals from emerging economies. Global Strategy Journal, 2(1): 26-40.

Mauri, A. J., \& Phatak, A. V. (2001). Global integration as inter-area product flows: The internalization of ownership and location factors influencing product flows across MNC units. Management International Review, 41(3), 233-249.

Meyer, K. E., Ding, Y., Li, J., \& Zhang, H. (2014). Overcoming distrust: How stateowned enterprises adapt their foreign entries to institutional pressures abroad. Journal of International Business Studies, 45(8): 1005-1028.

Meyer, K. E., Mudambi, R., \& Narula, R. (2011). Multinational enterprises and local contexts: the opportunities and challenges of multiple embeddedness. Journal of Management Studies, 48(2), 235-252.

Morck, R., Yeung, B., \& Zhao, M. Y. (2008). Perspectives on China's outward foreign direct Investment. Journal of International Business Studies, 39(3), 337-350.

Nayyar, D. (2008). The Internationalization of Firms from India: Investment, Mergers, and Acquisitions. Oxford Development Studies, 36(1), 111-131.

Nguyen, Q. T. K., \& Rugman, A. M. (2015a). Internal equity financing and the performance of multinational subsidiaries in emerging economies. Journal of International Business Studies. 46(4), 468-490.

Nguyen, Q. T. K., \& Rugman, A. M. (2015b). Multinational subsidiary sales and performance in South East Asia. International Business Review, 24(1), 115-123. 
Nolan, P. H. 2005. China at the crossroads. Journal of Chinese Economic and Business Studies, 3(1), 1-22.

Organization for Economic Cooperation and Development (OECD) (2008). OECD Reviews of Innovation Policy: China. OECD Publishing.

Organization for Economic Cooperation and Development (OECD) (2009). State Owned Enterprises in China: Reviewing the Evidence, Occasional Paper: 26 January. Pan, Y., Teng, L., Supapol, B. A., Lu, X., Huang, D., \& Wang, Z. (2014). Firms' FDI ownership: the influence of government ownership and legislative connections. Journal of International Business Studies, 45(8), 1029-1043.

Peng, M. W. (2012). The global strategy of emerging multinationals from China', Global Strategy Journal, 2(2), pp. 97-107.

Pérez-Nordtvedt, L., Babakus, E., \& Kedia, B. L. (2010). Learning from international business affiliates: developing absorptive capacity through networks and knowledge acquisition. Journal of International Management, 16(3): 262-274.

Prahalad, C. K., \& Doz, Y. L. (1987). The multinational mission: Balancing local demands and global vision. New York: The Free Press.

Podsakoff, P. M., MacKenzie, S. B., Lee, J. Y., \& Podsakoff, N. P. (2003). Common method biases in behavioral research: A critical review of the literature and recommended remedies, Journal of Applied Psychology, 88(5), 879-903.

Podsakoff, P. M., \& Organ, D. W. (1986). Self-reports in organizational research: Problems and prospects. Journal of Management, 12(4), 69-82.

Ramachandran, J. \& Pant, A. (2010). The liabilities of origin: An emerging economy perspective on the costs of doing business abroad. In D. Timothy, P. Torben \& T. Laszlo (Eds.). The Past, Present and Future of International Business \& Management, 
Advances in International Management (pp. 231-265). Bingley: Emerald Group Publishing.

Ramamurti, R. (2009). What have we learned about emerging market MNEs? In R, Ramamurti \& J, Singh (Eds.). Emerging multinationals in emerging markets (pp. 399426). Cambridge, U.K: Cambridge University Press.

Ramamurti, R. (2012). What is really different about emerging market multinationals? Global Strategy Journal, 2(1): 41-47.

Roth, K., \& Morrison, A. J. (1990). An empirical analysis of the integrationresponsiveness framework in global industries. Journal of International Business Studies, 21(4), 541-564.

Rugman, A. M. (2002). The influence of "managing across borders" on the field of international management. Advances in Comparative International Management, 14: $37-56$.

Rugman, A. M. (2010). Reconciling internalization theory and the eclectic paradigm. Multinational Business Review, 18(2), 1-12.

Rugman, A. M., \& Li, J. (2007). Will China's multinationals succeed globally or regionally? European Management Journal, 25(5), 333-343.

Rugman, A. M., \& Nguyen, Q. T. K. (2014). Modern international business theory and emerging economy multinational companies. In A. Cuervo-Cazurra, \& R. Ramamurti (Eds.), Understanding Multinationals from Emerging Markets (pp. 53-80). Cambridge University Press: Cambridge.

Rugman, A. M., Nguyen, Q. T. K., \& Wei, Z. Y. (2014). Chinese multinationals and public policy. International Journal of Emerging Markets, 9(2), 205-215. 
Rugman, A.M., Nguyen, Q.T.K., \& Wei, Z. (2016). Rethinking the literature on the performance of Chinese multinational enterprises. Management and Organization Review, 12(2), 269-302.

Rugman, A. M., \& Verbeke, A. (1992). A note on the transnational solution and the transaction cost theory of multinational strategic management. Journal of International Business Studies, 23(4), 761-771.

Rugman, A. M., \& Verbeke, A. (2001). Subsidiary-specific advantages in multinational enterprises. Strategic Management Journal, 22(3), 237-250.

Rugman, A. M., \& Verbeke, A. (2008). Internalization theory and its impact on the field of international business. In Boddewyn, J. J. (Ed.). International business scholarship: AIB fellows on the first 50 years and beyond (research in global strategic management) (pp.155-174). Emerald Group Publishing Limited.

Rugman, A. M., \& Verbeke, A. (2003). Extending the theory of the multinational enterprise: Internalization and strategic management perspectives. Journal of International Business Studies, 34(2), 125-137.

Rugman, A. M., Verbeke, A., \& Quyen, T. K. N. (2011). Fifty years of international business theory and beyond. Management International Review, 51(6), 755-786.

Rui, H., \& Yip, G. S. (2008). Foreign acquisitions by Chinese firms: A strategic intent perspective. Journal of World Business, 43(2), 213-226.

Slangen, A., \& Hennart, J. F. (2007). Greenfield or acquisition entry: A review of the empirical foreign establishment mode literature. Journal of International Management, 13(4), 403-429.

Slangen, A., \& Hennart, J. F. (2008). Do multinationals really prefer to enter culturally distant countries through greenfields rather than through acquisitions? the role of parent 
experience and subsidiary autonomy. Journal of International Business, 39(3), 472490.

Shi, W., Markóczy, L., \& Stan, C. (2014). The continuing importance of political ties in China. Academy of Management Perspective, 28 (1), 57-75.

The Economist. State-owned enterprises Fixing China Inc. (2004).

http://www.economist.com/news/china/21614240-reform-state-companies-back-

agenda-fixing-china-inc Accessed 07.02.16.

The Economist. Reform: The good, the bad and the ugly. (2015).

http://www.economist.com/news/special-report/21663333-bloated-state-owned-

sector-must-be-reformed-so-private-firms-can-compete-equal Accessed 07.02.16.

Thite, M., Wilkinson, A., \& Shah, D. (2012). HRM strategies and practices across subsidiaries in multinational corporations from emerging economies - a conceptual perspective. Journal of World Business, 47(2), 251-258.

Wang, C. Q., Hong, J. J., \& Kafouros, M., \& Wright, M. (2012). Exploring the role of government involvement in outward FDI from emerging economies. Journal of International Business Studies, 43(7), 655-676.

Wang, S. L., Luo, Y., Lu, X., Sun, J., \& Maksimov, V. (2014). Autonomy delegation to foreign subsidiaries: An enabling mechanism for emerging market multinationals. Journal of International Business Studies, 45(2), 111-130.

Wei, Z. Y. (2010). The literature on Chinese outward FDI. Multinational Business Review, 18(3), 73-112.

Westney, D. E., \& Zaheer, S. (2009). The multinational enterprise as an organization. In A. M. Rugman, \& T. L. Brewer (Eds.). The oxford handbook of international business. Oxford: Oxford University Press.

Witt, M., \& Lewin, A. Y. (2007). Outward foreign direct investment as escape response 
to home country institutional constraints. Journal of International business studies, 38(4), 579-594.

Xu, D., \& Shenkar, O. (2002). Institutional distance and the multinational enterprise. The Academy of Management Review: 27(4), 608-618.

Xu, E., \& Zhang, H. (2008). The impact of state shares on corporate innovation strategy and performance in China. Asia Pacific Journal of Management, 25(3), 473-487.

Zhang, D., \& Freestone, O. (2013). China's unfinished state-owned enterprise reforms Economic Roundup, 2, 79-102. 
Figure 1: Conceptual model

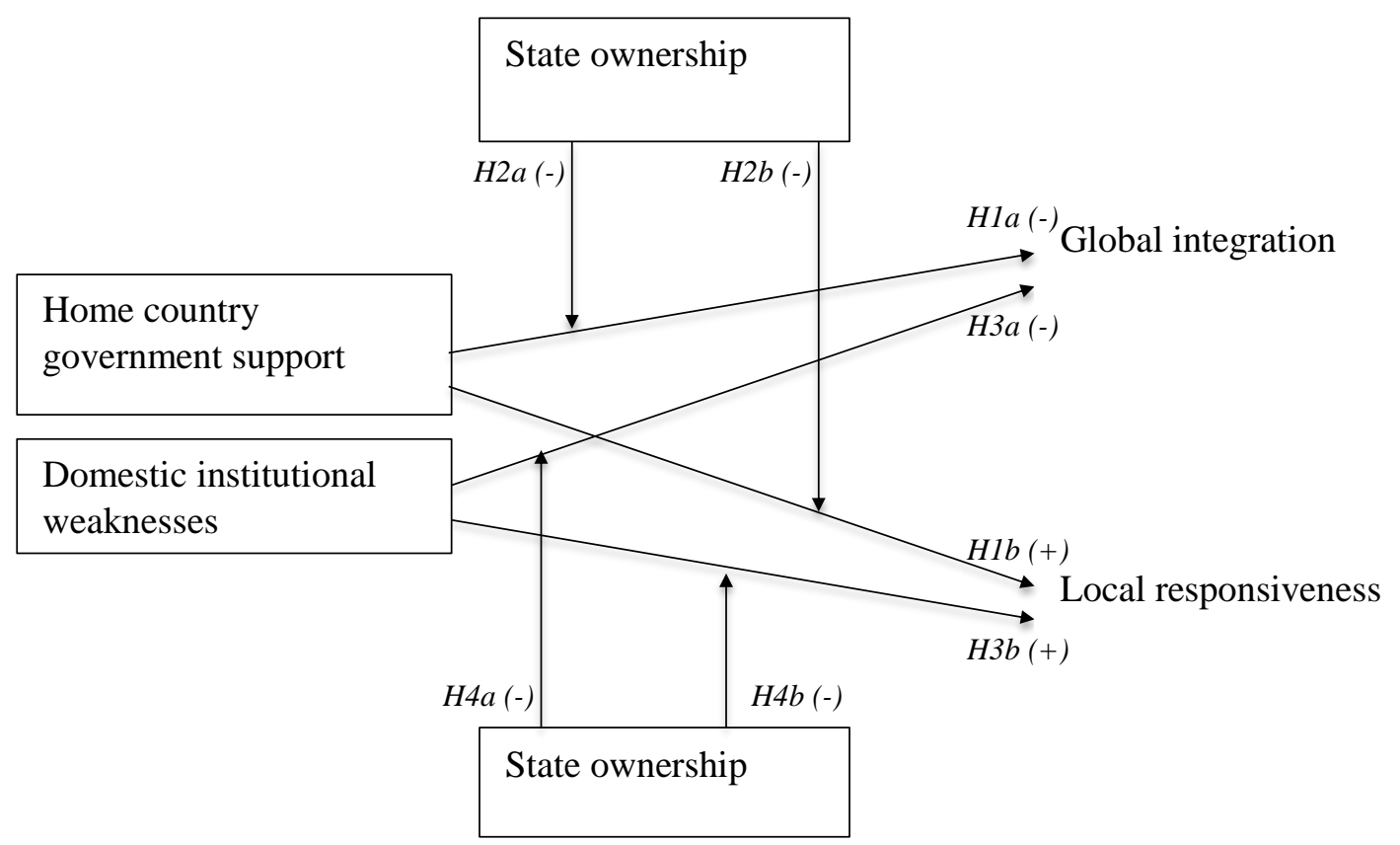


Figure 2: Moderating effects of state ownership: interaction effects of state ownership and domestic institutional weaknesses on (a) global integration and (b) local responsiveness

(a)

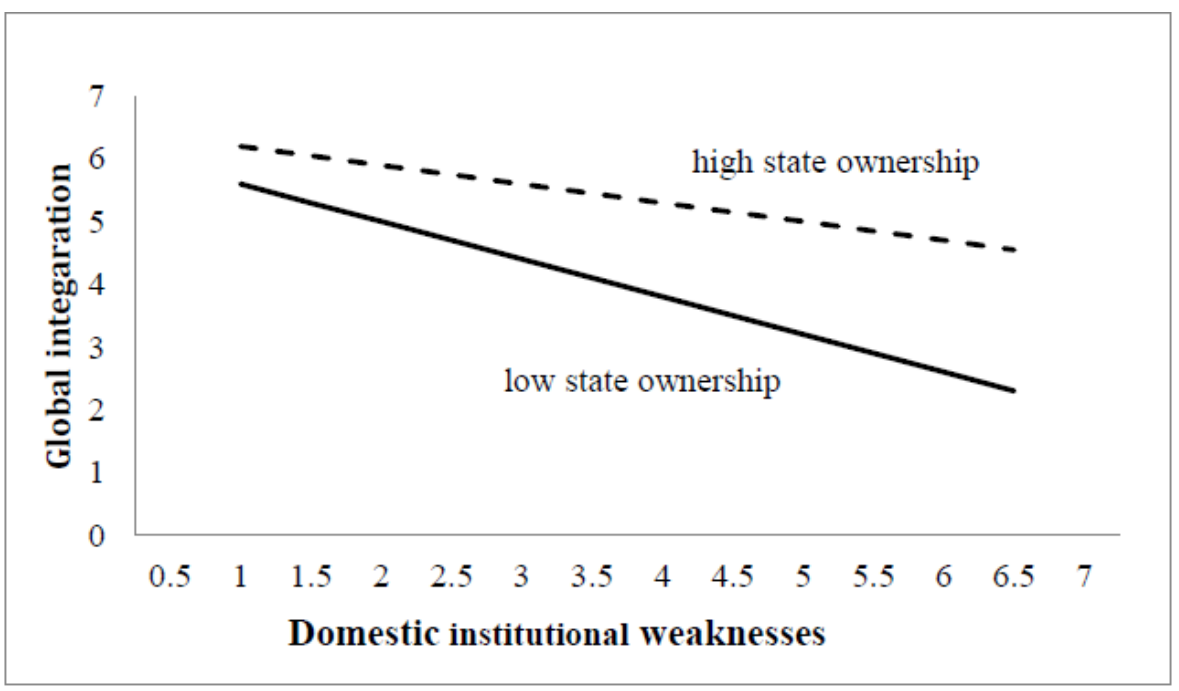

(b)

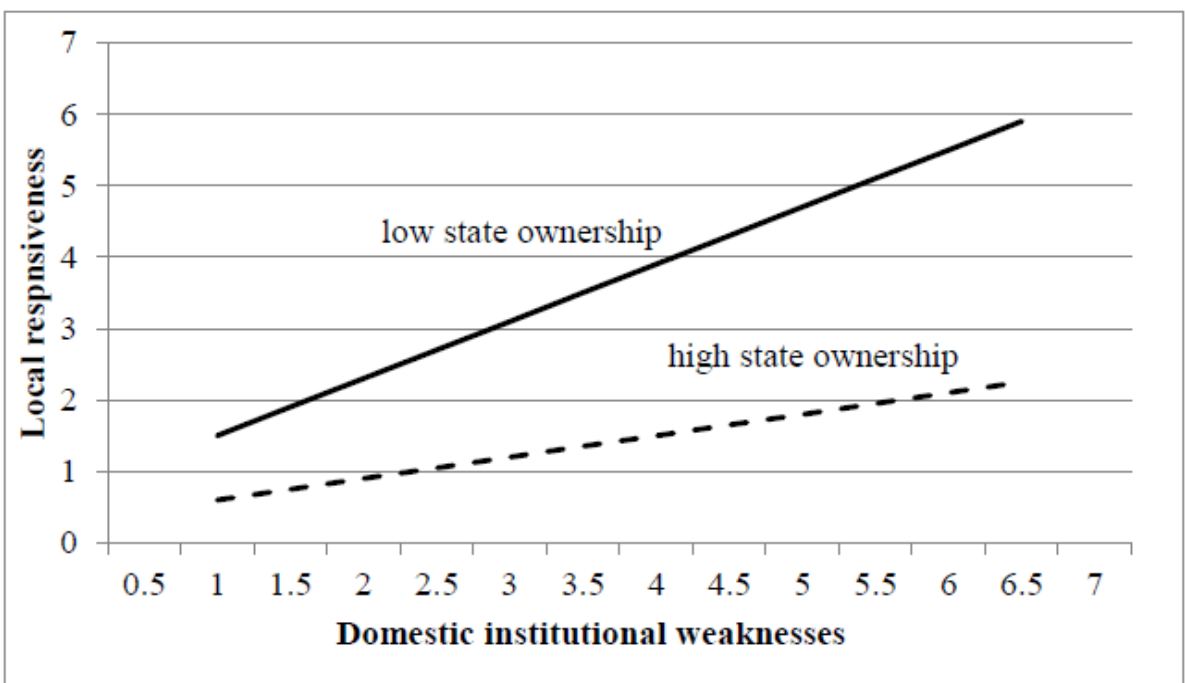


Table 1: Reliability and validity assessment

\begin{tabular}{|c|c|c|}
\hline Construct & Measurement on 7-point Likert scale & $\begin{array}{l}\text { Factor } \\
\text { loading }\end{array}$ \\
\hline $\begin{array}{l}\text { Global integration } \\
\text { (Cronbach's }\end{array}$ & $\begin{array}{l}\text { After foreign entry, to what extent your subsidiary shared parent } \\
\text { firms' resources with respect to: }\end{array}$ & \\
\hline alpha $=0.811$ & 1. raw material and intermediate products & 0.71 \\
\hline \multirow[t]{6}{*}{$\mathrm{AVE}=0.699)$} & 2. manufacturing know-how & 0.74 \\
\hline & 3. $\mathrm{R} \& \mathrm{D}$ resources & 0.82 \\
\hline & 4. the use of brand names & 0.75 \\
\hline & 5. marketing know-how & 0.73 \\
\hline & 6. sales channels & 0.81 \\
\hline & 7. management expertise & 0.84 \\
\hline $\begin{array}{l}\text { Local responsiveness } \\
\text { (Cronbach's } \\
\text { alpha }=0.856\end{array}$ & $\begin{array}{l}\text { After foreign entry, the subsidiary responded actively to local } \\
\text { environment, and adopted different products and customer service et } \\
\text { al. for each of the following factor }\end{array}$ & \\
\hline \multirow[t]{4}{*}{$\mathrm{AVE}=0.812)$} & 1. local customer needs & 0.85 \\
\hline & 2. local government policies & 0.89 \\
\hline & 3. local market conditions & 0.75 \\
\hline & 4. local rivalry situation & 0.81 \\
\hline $\begin{array}{l}\text { Home country } \\
\text { government support }\end{array}$ & $\begin{array}{l}\text { At the time of entry, to what extent your subsidiary had Chinese } \\
\text { government support when considering the following factors? }\end{array}$ & \\
\hline (Cronbach's & 1. financial support during investment & 0.83 \\
\hline \multirow[t]{4}{*}{$\begin{array}{l}\text { alpha }=0.804 \\
\mathrm{AVE}=0.586)\end{array}$} & $\begin{array}{l}\text { 2. information about investment opportunities, market analysis and } \\
\text { host country environment }\end{array}$ & 0.79 \\
\hline & $\begin{array}{l}\text { 3. privileged access to domestic education markets and sources of } \\
\text { scientific and technical research }\end{array}$ & 0.73 \\
\hline & $\begin{array}{l}\text { 4. government signed mutual investment agreements with host } \\
\text { countries }\end{array}$ & 0.69 \\
\hline & $\begin{array}{l}\text { 5. government provides personal accident insurance to expatriates } \\
\text { working abroad }\end{array}$ & 0.70 \\
\hline $\begin{array}{l}\text { Domestic institutional } \\
\text { weaknesses } \\
\text { (Cronbach's }\end{array}$ & $\begin{array}{l}\text { At the time of entry, to what extent was the decision to } \\
\text { establish/acquire the subsidiary influenced by the following } \\
\text { institutional factors in China? }\end{array}$ & \\
\hline alpha $=0.790$ & 1. domestic imperfect capital market & 0.71 \\
\hline \multirow[t]{2}{*}{$\mathrm{AVE}=0.674)$} & 2. weak intellectual property rights and legal frameworks & 0.80 \\
\hline & $\begin{array}{l}\text { 3. decentralization of the economic system and government } \\
\text { administration }\end{array}$ & 0.75 \\
\hline $\begin{array}{l}\text { Competition } \\
\text { (Cronbach's } \\
\text { alpha }=0.834\end{array}$ & $\begin{array}{l}\text { 1. At the time of entry, to what extent did you think the product } \\
\text { market in which your company participates is competitive amongst } \\
\text { existing rivals? }\end{array}$ & 0.76 \\
\hline $\mathrm{AVE}=0.642)$ & $\begin{array}{l}\text { 2. At the time of entry, to what extent did you think the product } \\
\text { market in which your company participates was competitive } \\
\text { amongst new entrants? }\end{array}$ & 0.72 \\
\hline $\begin{array}{l}\text { Demand heterogeneity } \\
\text { (Cronbach's } \\
\text { alpha }=0.767\end{array}$ & $\begin{array}{l}\text { 1. At the time of entry, to what extent did you think the demand } \\
\text { for your products within a host market is segmented according to } \\
\text { region, income, gender, education, or other demographic attributes? }\end{array}$ & 0.78 \\
\hline $\mathrm{AVE}=0.592)$ & $\begin{array}{l}\text { 2. Following the above question, to what extent did you think the } \\
\text { demand for your products within each segmented market is } \\
\text { diverse? }\end{array}$ & 0.76 \\
\hline
\end{tabular}

Note: AVE: Average Variance Extracted 
Table 2: Respondents' characteristics

\section{Subsidiary ( $N=124$; data in percentage)}

A. Entry strategy

Greenfield

Acquisition

\section{State ownership}

State owned

Non-state owned

\section{E. Host countries:}

Developed countries

(including):

The United States

Europe

Oceania

Others

\section{B. Ownership}

64.52 Wholly-owned

58.87

Joint venture

41.13

\section{Investment size}

$41.13 \quad 100$ and above $\quad 7.1$

$\begin{array}{lll}58.87 & 50 \sim 100 & 9.0\end{array}$

$1 \sim 10 \quad 42.6$

1 and below 41.3

62.10 Developing countries $\quad 37.90$

(including):

$\begin{array}{lll}25.00 & \text { Asia } & 26.61\end{array}$

$\begin{array}{lll}18.55 & \text { Africa } & 8.06\end{array}$

6.45 Other 3.23 
Table 3: Descriptive statistics and correlation $(\mathrm{N}=124)$

\begin{tabular}{|c|c|c|c|c|c|c|c|c|c|c|c|}
\hline \multicolumn{12}{|l|}{ Variables } \\
\hline & 1 & 2 & 3 & 4 & 5 & 6 & 7 & 8 & 9 & 10 & 11 \\
\hline Mean & 4.30 & 3.63 & 4.74 & 3.87 & 0.34 & 0.03 & 0.35 & 0.59 & 4.19 & 4.06 & 0.62 \\
\hline S.D. & 1.45 & 1.17 & 2.09 & 1.66 & 0.29 & 0.08 & 0.19 & 0.48 & 1.39 & 1.33 & 3.22 \\
\hline 1. Global integration & 1 & & & & & & & & & & \\
\hline 2. Local responsiveness & -0.049 & 1 & & & & & & & & & \\
\hline 3. Home country government support & -0.324 & 0.255 & 1 & & & & & & & & \\
\hline 4. Domestic institutional weaknesses & -0.193 & 0.298 & -0.091 & 1 & & & & & & & \\
\hline 5. State ownership & 0.053 & -0.031 & 0.179 & -0.219 & 1 & & & & & & \\
\hline 6. Subsidiary size & 0.102 & 0.293 & 0.099 & -0.133 & 0.148 & 1 & & & & & \\
\hline 7. Establishment mode & -0.077 & 0.099 & -0.064 & 0.103 & 0.063 & 0.129 & 1 & & & & \\
\hline 8. Equity ownership & 0.055 & -0.105 & -0.031 & -0.032 & -0.036 & 0.012 & -0.188 & 1 & & & \\
\hline 9. Competition & 0.109 & 0.036 & 0.025 & 0.003 & -0.026 & -0.176 & -0.039 & -0.049 & 1 & & \\
\hline 10. Demand heterogeneity & -0.214 & 0.152 & 0.042 & 0.026 & -0.089 & -0.061 & -0.148 & -0.070 & 0.133 & 1 & \\
\hline 11. Host country economic development & -0.107 & -0.218 & 0.015 & 0.187 & -0.040 & 0.102 & 0.011 & -0.125 & 0.050 & 0.061 & 1 \\
\hline
\end{tabular}


Table 4: OLS regression results with the global integration as dependent variable

\begin{tabular}{|c|c|c|c|c|}
\hline \multirow{2}{*}{$\begin{array}{l}\text { Variables } \\
\text { (Constant) }\end{array}$} & Model 1 & Model 2 & Model 3 & Model 4 \\
\hline & $\begin{array}{c}2.653 * * * \\
(0.562)\end{array}$ & $\begin{array}{c}3.167 * * * \\
(0.668)\end{array}$ & $\begin{array}{c}2.702 * * * \\
(0.565)\end{array}$ & $\begin{array}{c}3.340 * * * \\
(0.676)\end{array}$ \\
\hline Inverse mills ratio (IMR) & $\begin{array}{c}0.036 \\
(0.003)\end{array}$ & $\begin{array}{c}0.040 \\
(0.003)\end{array}$ & $\begin{array}{c}0.040 \\
(0.003)\end{array}$ & $\begin{array}{c}0.042 \\
(0.003)\end{array}$ \\
\hline Subsidiary size & $\begin{array}{c}1.657 \\
(1.434)\end{array}$ & $\begin{array}{c}1.565 \\
(1.447)\end{array}$ & $\begin{array}{c}1.565 \\
(1.438)\end{array}$ & $\begin{array}{c}1.443 \\
(1.445)\end{array}$ \\
\hline Establishment mode & $\begin{array}{l}-0.562^{\prime} \\
(0.294)\end{array}$ & $\begin{array}{l}-0.559^{\prime} \\
(0.074)\end{array}$ & $\begin{array}{l}-0.570^{\prime} \\
(0.055)\end{array}$ & $\begin{array}{l}-0.576 \\
(0.0650\end{array}$ \\
\hline Equity ownership & $\begin{array}{c}1.127 * * * \\
(0.271)\end{array}$ & $\begin{array}{c}1.111 * * * \\
(0.275)\end{array}$ & $\begin{array}{c}1.109 * * * \\
(0.272)\end{array}$ & $\begin{array}{c}1.081 * * * \\
(0.275)\end{array}$ \\
\hline Competition & $\begin{array}{c}0.065 \\
(0.080)\end{array}$ & $\begin{array}{c}0.062 \\
(0.080)\end{array}$ & $\begin{array}{c}0.056 \\
(0.080)\end{array}$ & $\begin{array}{c}0.051 \\
(0.080)\end{array}$ \\
\hline Demand heterogeneity & $\begin{array}{c}-0.193 * \\
(0.084)\end{array}$ & $\begin{array}{c}-0.200 * \\
(0.084)\end{array}$ & $\begin{array}{l}-0.189 * \\
(0.084)\end{array}$ & $\begin{array}{c}-0.196 * \\
(0.084)\end{array}$ \\
\hline $\begin{array}{l}\text { Host country economic } \\
\text { development }\end{array}$ & $\begin{array}{l}-0.388 \\
(0.286)\end{array}$ & $\begin{array}{l}-0.337 \\
(0.290)\end{array}$ & $\begin{array}{l}-0.371 \\
(0.288)\end{array}$ & $\begin{array}{l}-0.307 \\
(0.292)\end{array}$ \\
\hline State ownership & $\begin{array}{l}0.107 * \\
(0.074)\end{array}$ & $\begin{array}{l}0.108 * \\
(0.074)\end{array}$ & $\begin{array}{l}0.107 * \\
(0.074)\end{array}$ & $\begin{array}{c}0.109 * \\
(0.073)\end{array}$ \\
\hline \multicolumn{2}{|c|}{ H1a Home country government support } & $\begin{array}{c}-0.244 * * \\
(0.131)\end{array}$ & & $\begin{array}{c}-0.288 * * \\
(0.101)\end{array}$ \\
\hline \multicolumn{2}{|c|}{ H3a Domestic institutional weaknesses } & $\begin{array}{c}-0.157 * \\
(0.050)\end{array}$ & & $\begin{array}{l}-0.133 * \\
(0.054)\end{array}$ \\
\hline \multicolumn{3}{|c|}{ H2a Home country government support x state ownership } & $\begin{array}{c}0.024 \\
(0.011)\end{array}$ & $\begin{array}{c}0.022 \\
(0.011)\end{array}$ \\
\hline \multicolumn{3}{|c|}{ H4a Domestic institutional weaknesses x state ownership } & $\begin{array}{c}0.173 * \\
(0.028)\end{array}$ & $\begin{array}{c}0.144 * \\
(0.035)\end{array}$ \\
\hline $\mathrm{N}$ & 124 & 124 & 124 & 124 \\
\hline F-value & $7.009 * * *$ & $7.680 * * *$ & $6.623 * * *$ & $6.906^{* * *}$ \\
\hline $\mathrm{R}^{2}$ & 0.280 & 0.352 & 0.297 & 0.397 \\
\hline Adjusted $\mathrm{R}^{2}$ & 0.240 & 0.301 & 0.261 & 0.344 \\
\hline
\end{tabular}


Table 5: OLS regression results with the local responsiveness as dependent variable

\begin{tabular}{|c|c|c|c|c|}
\hline Variables & Model 1 & Model 2 & Model 3 & Model 4 \\
\hline (Constant) & $\begin{array}{l}4.242 * * * \\
(0.455)\end{array}$ & $\begin{array}{c}4.307 * * * \\
(0.543)\end{array}$ & $\begin{array}{l}4.268 * * * \\
(0.460)\end{array}$ & $\begin{array}{c}4.340 * * * \\
(0.555)\end{array}$ \\
\hline Inverse mills ratio (IMR) & $\begin{array}{c}0.020 \\
(0.002)\end{array}$ & $\begin{array}{c}0.023 \\
(0.002)\end{array}$ & $\begin{array}{c}0.022 \\
(0.002)\end{array}$ & $\begin{array}{c}0.024 \\
(0.002)\end{array}$ \\
\hline Subsidiary size & $\begin{array}{c}0.596 \\
(1.163)\end{array}$ & $\begin{array}{c}0.766 \\
(1.176)\end{array}$ & $\begin{array}{c}0.621 \\
(1.171)\end{array}$ & $\begin{array}{c}0.780 \\
(1.186)\end{array}$ \\
\hline Establishment mode & $\begin{array}{l}0.104 * \\
(0.238)\end{array}$ & $\begin{array}{l}0.096 * \\
(0.252)\end{array}$ & $\begin{array}{l}0.106^{*} \\
(0.240)\end{array}$ & $\begin{array}{l}0.092 * \\
(0.254)\end{array}$ \\
\hline Equity ownership & $\begin{array}{l}-0.388 \\
(0.220)\end{array}$ & $\begin{array}{l}-0.346 \\
(0.224)\end{array}$ & $\begin{array}{l}-0.392 \\
(0.221)\end{array}$ & $\begin{array}{l}-0.353 \\
(0.226)\end{array}$ \\
\hline Competition & $\begin{array}{c}0.020 \\
(0.065)\end{array}$ & $\begin{array}{c}0.018 \\
(0.065)\end{array}$ & $\begin{array}{c}0.022 \\
(0.066)\end{array}$ & $\begin{array}{c}0.020 \\
(0.066)\end{array}$ \\
\hline Demand heterogeneity & $\begin{array}{l}0.175^{*} \\
(0.068)\end{array}$ & $\begin{array}{l}0.180 * * \\
(0.068)\end{array}$ & $\begin{array}{l}0.172 * \\
(0.068)\end{array}$ & $\begin{array}{l}0.170 * \\
(0.069)\end{array}$ \\
\hline $\begin{array}{l}\text { Host country economic } \\
\text { development }\end{array}$ & $\begin{array}{c}-0.362 * * \\
(0.232)\end{array}$ & $\begin{array}{c}-0.398 * * \\
(0.236)\end{array}$ & $\begin{array}{c}-0.381 * * \\
(0.235)\end{array}$ & $\begin{array}{c}-0.413 * * \\
(0.239)\end{array}$ \\
\hline State ownership & $\begin{array}{c}-0.203 * * \\
(0.068)\end{array}$ & $\begin{array}{c}-0.194 * * \\
(0.058)\end{array}$ & $\begin{array}{c}-0.223^{* *} \\
(0.070)\end{array}$ & $\begin{array}{c}-0.186 * * \\
(0.050)\end{array}$ \\
\hline \multicolumn{2}{|c|}{ H1b Home country government support } & $\begin{array}{c}0.171 \\
(0.066)\end{array}$ & & $\begin{array}{c}0.158 \\
(0.053)\end{array}$ \\
\hline \multicolumn{2}{|c|}{ H3b Domestic institutional weaknesses } & $\begin{array}{c}0.323^{* * * *} \\
(0.088)\end{array}$ & & $\begin{array}{c}0.319 * * * \\
(0.083)\end{array}$ \\
\hline \multicolumn{3}{|c|}{ H2b Home country government support x state ownership } & $\begin{array}{l}-0.041 \\
(0.034)\end{array}$ & $\begin{array}{l}-0.045 \\
(0.030)\end{array}$ \\
\hline \multicolumn{3}{|c|}{ H4b Domestic institutional weaknesses x state ownership } & $\begin{array}{c}-0.063 * \\
(0.028)\end{array}$ & $\begin{array}{c}-0.080 * \\
(0.045)\end{array}$ \\
\hline $\mathrm{N}$ & 124 & 124 & 124 & 124 \\
\hline F-value & 4.643 & 6.282 & 4.152 & 5.289 \\
\hline $\mathrm{R}^{2}$ & 0.200 & 0.237 & 0.217 & 0.279 \\
\hline Adjusted $\mathrm{R}^{2}$ & 0.159 & 0.175 & 0.167 & 0.214 \\
\hline
\end{tabular}


